\title{
Efek Kemopreventif Ekstrak Metanol Kulit Kayu Nangka (Artocarpus heterophylla Lmk.) pada Karsinogenesis Kanker Payudara Tikus Betina yang Diinduksi DMBA
}

\section{Chemopreventive Effect of Mathanolic Extract from Jackfruit Bark (Artocarpus heterophylla Lmk.) on The Carcinogenesis of Rat Breast Cancer Development by DMBA Inducedment}

\author{
Susilowati \\ Fakultas Farmasi Universitas Muhammadiah Surakarta \\ JL. Ahmad Yani Tromol pos 1 Pabelan Surakarta ; abisalumisri@gmail.com
}

\section{Intisari}

Upaya penemuan senyawa kemopreventif yang mampu menghambat dan menekan proses karsinogenesis merupakan strategi pencegahan kanker yang perlu dikembangkan. Tanaman nangka (Artocarpus heterophylla Lmk.) telah dilaporkan memiliki banyak kandungan senyawa kimia yang berpotensi sebagai antikanker. Penelitian ini bertujuan untuk mengetahui potensi antikarsinogenesis ekstrak metanol kulit kayu nangka pada kanker payudara tikus betina yang diinduksi dengan 7,12-Dimethylbenz(a)antrhacene (DMBA) selama fase inisiasi dan post inisiasi kanker.

Pada penelitian ini 25 ekor tikus betina galur Sprague-Dawley umur 47 hari dengan berat badan 50-150 g dibagi menjadi 5 kelompok. Kelompok I, II dan III merupakan kelompok uji dengan urutan dosis ekstrak $200 \mathrm{mg} / \mathrm{kg}$ BB, $400 \mathrm{mg} / \mathrm{kg}$ BB dan $800 \mathrm{mg} / \mathrm{kg}$ BB. Kelompok IV (kelompok pembanding) sebagai kontrol positif (Tamoxifen 0,36 mg/200 g BB) dan kelompok $\mathrm{V}$ (kelompok sakit) sebagai kontrol negatif ( $2 \mathrm{ml} / 200 \mathrm{~g}$ BB CMC Na 0,5\%). DMBA (20 $\mathrm{mg} / \mathrm{kg}$ BB) diberikan secara peroral dua kali perminggu selama lima minggu. Sediaan ekstrak dan kontrol diberikan setiap hari selama 7 minggu bersamaan dengan induksi DMBA. Pengamatan dilakukan secara makroskopis dan mikroskopis.

Hasil penelitian menunjukkan belum dapat diketahui potensi penghambatan pertumbuhan tumor mamae oleh ekstrak metanol kulit kayu nangka karena masih perlu adanya optimasi terhadap model induksi karsinogenesis kanker payudara.

Kata kunci: Kemopreventif, nangka (Artocarpus heterophylla Lmk.), DMBA

\begin{abstract}
Chemopreventive compound discovery efforts that could inhibit and suppress the process need to be developed of carcinogenesis that is cancer prevention strategies. Jackfruit (Artocarpus heterophylla Lmk.) have been reported many chemical compounds that potent as anti-cancer properties. The aim of this research is to determine the potential anticarsinogenesis of methanolic extract of jackfruit bark to
\end{abstract}





\section{Efek Kemopreventif Ekstrak Metanol Kulit Kayu Nangka (Artocarpus heterophylla}

Lmk.) pada Karsinogenesis Kanker Payudara

suppress 7,12-Dimethylbenz(a)antrhacene (DMBA) induced breast cancer female development during the initiation phase and post initiation of cancer.

In this research 25 female Sprague-Dawley rats aged 47 days with 50-150 g body weight divided into 5 groups. Group I, II and III is a test group with extract dose of 200, 400 and $800 \mathrm{mg} / \mathrm{kg} \mathrm{BW.} \mathrm{Group}$ IV (comparison group) as a positive control $(0.36 \mathrm{mg} / 200 \mathrm{~g}$ tamoxifen $B B$ ) and group $V$ (the pain group) as a negative control (2 ml/200 g BB $\mathrm{Na} C M C 0.5 \%)$. DMBA (20 mg / kg) peroral given twice a week for five weeks. Extract and control treatment is given every day for 7 weeks with DMBA induction. Tumor development was examined by macroscopic and microscopic.

The results showed that the potential of methanolic extract of jackfruit bark to suppress breast cancer development is unknown because still necessary to optimize the induction of breast cancer carcinogenesis models.

\section{Keywords: Chemopreventive, Jackfruit (Artocarpus heterophylla Lmk.), DMBA}

\section{PENDAHULUAN}

Kanker payudara dan leher rahim merupakan dua macam kanker yang frekuensi kejadiannya paling tinggi di antara kanker-kanker jenis lain yang sering menyerang wanita (Tjindarbumi dan Mangunkusumo, 2002). Kanker payudara menduduki peringkat pertama $(32 \%)$ di Amerika Serikat dan kematian karena kanker jenis ini mencapai 18\% (King, 2000). Kejadian kanker payudara di Indonesia menduduki peringkat kedua setelah kanker leher rahim di antara kanker yang menyerang wanita (Wiludjeng dan Turniani, 2005).

Metode pengobatan terhadap kanker saat ini, dilakukan dengan pembedahan, terapi radiasi dan kemoterapi dengan atau tanpa obat. Usaha tersebut belum mampu secara efektif menanggulangi terjadinya kanker, dikarenakan batas keamanannya yang sempit dan rendahnya selektifitas obatobat antikanker pada kemoterapi dengan obat (Gunawan, 2007).

Upaya pencegahan kanker yang menjanjikan dapat dilakukan melalui pemberian senyawa kemopreventif (Gerhauser, 2008). Senyawa tersebut merupakan senyawa yang dapat menghambat dan menekan proses karsinogenesis pada manusia, sehingga pertumbuhan kanker dapat dicegah (Kakizoe, 2003). Usaha penemuan senyawa kemopreventif dari bahan alam (fitokimia), berasal dari senyawa kimia yang telah diisolasi dari berbagai tanaman dan diantaranya terbukti memiliki aktivitas biologi terhadap berbagai jenis kanker (Sampurno, 2003).

Tanaman nangka (Artocarpus heterophylla Lmk.) merupakan spesies tumbuhan dari genus Artocarpus yang telah dilaporkan memiliki banyak kandungan senyawa kimia yang berpotensi sebagai antikanker. Beberapa kandungan senyawa kimia tersebut antara lain senyawa-senyawa flavonoid baru yakni morusin, artonin E, sikloartobilosanton, dan artonol B (Ersam, 2001), senyawa flavon yang memiliki bioaktivitas sebagai antitumor pada sel leukemia L 1210 serta artokarpin dan artonin $\mathrm{E}$ yang merupakan senyawa turunan flavonoid dengan efek sitotoksik terhadap beberapa sel kanker seperti A549 (sel kanker paru-paru), MCF-7 dan MDAMB-231 (sel kanker payudara), IA9, HCT8 (sel kanker usus), KB, KB-Vin dan P388 (Suhartati, 2001; Syah, 2005). Penelitian lain menunjukkan artokarpin hasil isolasi kulit kayu nangka berpotensi sebagai obat anti kanker kulit, dengan adanya efek sitotoksisitas pada proliferasi sel melanoma B16 ( $\mathrm{IC}_{50} 10,3 \mu \mathrm{M}$ ) (Arung et al., 2008). Oleh karena itu, perlu dilakukan penelitian terhadap penghambatan karsinogenesis kanker 
payudara yang diinduksi dengan DMBA (7,12-dimetbylben 2 (a)antrhacene) pada tikus betina oleh ekstrak metanol kulit kayu nangka sebagai salah satu usaha penemuan senyawa kemopreventif dari bahan alam dan dapat dipergunakan sebagai dasar pengembangan selanjutnya bagi penemuan obat antikanker.

\section{METODE PENELITIAN}

A. Alat dan Bahan

Alat yang digunakan untuk pembuatan ekstrak meliputi almari pengering, evaporator, cawan porselin, penangas air, timbangan, kertas saring dan peralatan-peralatan gelas, sedangkan alat uji antikarsinogenesis adalah spuit per oral, beaker glass, sonicator, vortex, flakon, mikroskop dan timbangan elektrik.

Bahan uji antikarsinogenesis meliputi ekstrak metanol kulit kayu nangka yang berasal dari daerah Blora, CMC-Na $0,5 \%$ sebagai pelarut, DMBA $0,2 \%$ dalam sesami oil (minyak wijen), Tamoxifen dan aquadest.

\section{B. Jalannya Penelitian}

\section{Pembuatan ekstrak metanol kulit kayu nangka}

Simplisia kulit kayu nangka kering dihaluskan dengan cara digiling dan \pm 4 $\mathrm{kg}$ simplisia tersebut dimaserasi dengan pelarut metanol. Selanjutnya maserat disaring dengan corong buchner, filtrat diuapkan dengan vaccum rotary evaporator, didapatkan ekstrak metanol kental dan dilanjutkan pengeringan di atas waterbath suhu $60-70^{\circ} \mathrm{C}$. Proses maserasi diulangi 3 kali.

2. Uji antikarsinogenesis ekstrak metanol kulit kayu nangka pada karsinogenesis kanker payudara tikus betina yang diinduksi DMBA

Tikus betina Sprague Dawley dipelihara dalam ruangan berventilasi cukup, suhu ruangan $29-32^{\circ} \mathrm{C}$ dan makanan dalam bentuk pellet BR-1 serta minuman air diberikan sekali sehari. Hewan diadaptasikan dalam kandang selama 1 minggu sebelum perlakuan. Umur tikus 47 hari dan berat badan 50100 g, dibagi menjadi 5 kelompok perlakuan sebagai berikut (bersamaan induksi DMBA):

- Kontrol negatif $\quad: 2 \mathrm{ml} / 200$ g BB CMC Na $0,5 \%$

- Kontrol positif : Tamoxifen 0,36 $\mathrm{mg} / 200 \mathrm{~g} \mathrm{BB}$

- Sediaan uji dosis I : $200 \mathrm{mg} / \mathrm{kg} \mathrm{BB}$

- Sediaan uji dosis II : $400 \mathrm{mg} / \mathrm{kg}$ BB

- Sediaan uji dosis III : $800 \mathrm{mg} / \mathrm{kg} \mathrm{BB}$

a. Pembuatan larutan karsinogen (DMBA 0,2\% dalam sesami oil)

Ditimbang seksama 100,0 $\mathrm{mg}$ DMBA (SIGMA) dan dilarutkan dalam 50 $\mathrm{ml}$ sesami oil. Proses pelarutan dipercepat dengan vortex. Larutan diberikan kepada hewan uji secara per oral dengan volume tidak melebihi volume maksimal yang diperbolehkan.

b. Pembuatan larutan tamoxifen dalam CMC-Na $\quad 0,5 \%$ (kontrol positif)

Dilakukan pembuatan volume stok $500 \mathrm{ml}$ tamoxifen $0,36 \mathrm{mg} / 200 \mathrm{~kg}$ BB dalam CMC-Na 0,5\%. 9 tablet tamoxan yang mengandung $90 \mathrm{mg}$ tamoxifen, kemudian digerus halus menggunakan mortir dan stempler, dilarutkan dalam $500 \mathrm{ml}$ CMC-Na 0,5\%. Proses pelarutan dipercepat dengan sonicator. Larutan diberikan kepada hewan uji secara peroral dengan volume tidak melebihi volume maksimal yang diperbolehkan yaitu $2 \mathrm{ml} / 200 \mathrm{~g}$ BB.

c. Pembuatan larutan uji (ekstrak metanol kulit kayu nangka)

Dilakukan pembuatan volume stok ekstrak dosis $800 \mathrm{mg} / \mathrm{kg}$ BB. Ditimbang 20 gram ekstrak metanol kulit kayu nangka dan disuspensikan dengan $250 \mathrm{ml}$ larutan $\mathrm{Na}$ CMC 0,5\%. Larutan diberikan kepada hewan uji secara peroral dengan volume tidak melebihi volume maksimal yang diperbolehkan yaitu 2 $\mathrm{ml} / 200 \mathrm{~g} \mathrm{BB}$.

d. Induksi karsinogenesis dengan DMBA dan perlakuan dengan ekstrak metanol kulit nangka Setiap kelompok terdiri dari 5 ekor tikus yang diinduksi dengan DMBA $20 \mathrm{mg} / \mathrm{kg}$ BB per oral pada saat umur 47 hari dan dilanjutkan seminggu dua kali 
sampai pemberian sepuluh kali. Perlakuan sediaan uji dan kontrol diberikan setiap hari secara per oral sejak umur 47 hari dilanjutkan sampai minggu ke-7 bersamaan iduksi DMBA.

e. Pengamatan makroskopi terhadap uji kemopreventif ekstrak metanol kulit kayu nangka

Pengamatan nodul tumor mammae secara palpasi dilakukan mulai minggu pertama sampai minggu ke 17 setelah inisiasi DMBA terakhir. Palpasi dilakukan $1-2 x$ setiap minggu dan menggunakan sarung tangan. Dicatat jumlah dan diameter nodul tumor masing-masing tikus pada form yang telah disiapkan. Tikus ditimbang setiap minggunya untuk mengamati perkembangan berat badan tikus hingga akhir pengamatan. Pada akhir minggu ke-17 setelah induksi, tikus dinekropsi dan nodul yang muncul diambil, kemudian besar tumor diukur dengan penggaris serta ditimbang beratnya.

\section{f. Pemeriksaan histopatologi}

Pada akhir pengamatan (minggu ke 17 setelah induksi DMBA), dilakukan nekropsi terhadap hewan uji. Analisis histopatologi dilakukan dengan pengecatan Haematoxillin dan Eosin serta AgNOR terhadap organ payudara, paruparu, hati, ginjal dan jantung untuk mengetahui keadaan sitologinya serta tingkat keparahan tumor/kanker yang terjadi. Analisis mikroskopis ini dilakukan dengan mengamati sifat karsinogenesis seluler pada jaringan yang diperiksa.

\section{Cara Analisis}

Insidensi tumor dihitung dari jumlah tikus yang terkena tumor pada setiap kelompok. Potensi penghambatan dihitung dari selisih jumlah tikus yang terkena tumor antara perlakuan ekstrak dan perlakuan DMBA dibagi jumlah tikus yang terkena tumor pada perlakuan DMBA dikali 100\%.

Untuk perkembangan berat badan dianalisis dengan uji anova one way dengan membandingkan data masingmasing kelompok hewan uji dari hasil selisih berat badan penimbangan minggu terakhir dikurangi berat badan minggu pertama dibagi jumlah minggu pengamatan berat badan.

Tumor multiplicity dihitung dari rata-rata jumlah nodul tumor setiap tikus dalam satu kelompok. Selanjutnya keberbedaan antar kelompok yang meliputi Insidensi tumor, Tumor multiplicity, dan jumlah NOR dari hasil pengecatan AgNOR dianalisis menggunakan statistik non parametik Kruskal Wallis dilanjutkan Mann-Whitney test dengan taraf kepercayaan $95 \%$.

\section{HASIL DAN PEMBAHASAN}

A. Model Pembuatan Kanker Payudara

Pembuatan model kanker payudara pada penelitian ini menggunakan senyawa karsinogen 7,12dimetilbenz(a)antrasen (DMBA), karena DMBA merupakan senyawa karsinogen yang spesifik untuk pembuatan model tumor mamae pada hewan percobaan jika diberikan secara peroral (Kubatka et al., 2002). Karsinogen ini termasuk golongan Polisiklik Aromatik Hidrokarbon dan merupakan karsinogen genetik yang melakukan aksinya dengan merusak molekul DNA dalam bentuk metabolitnya (Dandekar et al., 1986).

Menurut Kubatka et a.l (2002), induksi karsinogenesis mamae pada tikus betina dipengaruhi oleh faktor umur, galur (strain), dosis dan waktu pemberian karsinogen, pola sistem imun, status sistem endokrin dan pakan. Oleh karena itu, berdasarkan Barros et al. (2004) penelitian ini menggunakan tikus betina galur Sprague Dawley karena lebih sensitif daripada Wistar dengan umur 47 hari yang merupakan awal pubertas, dimana kesempatan induksi karsinogenesis mamae yang paling baik.

Penetapan dosis serta frekuensi induksi DMBA pada penelitian ini, didasarkan pada penelitian Susilowati (2004) dan Meiyanto et al. (2007) yang menunjukan bahwa pemberian karsinogen multiple dose lebih meningkatkan insidensi atau frekuensi terjadinya tumor dari pada single dose. Oleh karena itu, pada penelitian 
ini dibuat waktu induksi DMBA secara peroral dengan dosis $20 \mathrm{mg} / \mathrm{kg}$ BB sebanyak 2 kali perminggu selama 5 minggu. Hasil penelitian menunjukkan kelompok sakit yaitu kelompok kontrol negatif (DMBA + CMC Na 0,5\%) hanya memiliki insidensi tumor 25\% (satu tikus timbul nodul dari $\mathrm{n}=4$ pada Tabel 2) dimana seharusnya terjadi insidensi $100 \%$. Berdasarkan hal tersebut, analisis hasil percobaan di bawah ini hanya berupa asumsi saja sehingga tidak dapat digunakan untuk mengetahui potensi penghambatan karsinogenesis dari ekstrak.

\section{B. Pengaruh Pemberian Ekstrak Terhadap Insidensi Tumor}

Nodul yang terlihat setelah pemberian DMBA pada beberapa tikus tidak hanya timbul di bagian puting tetapi pada bagian leher dan pinggul (Tabel 1). $\mathrm{Hal}$ ini dikarenakan tikus betina mempunyai 6 pasang puting dimana kelenjar payudaranya bercabang sepanjang milk line dari cervical (tengkuk) hingga inguinal (selangkangan), sehingga kanker biasa tumbuh di sepanjang milke line tersebut (Russo and Russo, 1996).

Presentase insidensi yang digambarkan dengan kurva survival (Gambar 1) menunjukkan pemberian ekstrak metanol kulit kayu nangka (Artocarpus heterophylla Lmk.) pada kanker payudara tikus yang diinduki dengan DMBA selama inisiasi dan post inisiasi selama 17 minggu dengan dosis ekstrak $200 \mathrm{mg} / \mathrm{kg} \mathrm{BB}$ dan $400 \mathrm{mg} / \mathrm{kg}$ BB mengurangi dan memperlama insidensi kanker mamae secara signifikan $(\mathrm{p}<0,05)$, sedangkan pada dosis ekstrak $800 \mathrm{mg} / \mathrm{kg}$ $\mathrm{BB}$ dan penggunaan Tamoxifen 0,36 $\mathrm{mg} / 200 \mathrm{~g}$ BB hanya mampu memperlama insidensinya secara signifikan.

Tabel 1. Tikus yang Timbul Nodul Setelah Pemeriksaan Selama 17 Minggu Pada MasingMasing Kelompok Perlakuan

\begin{tabular}{|c|c|c|c|}
\hline No & Kelompok perlakuan/ tikus no & Letak nodul & Ukuran nodul \\
\hline 1 & $\begin{array}{l}\text { Kelompok I } \\
\text { (Kontrol Negatif CMC Na 0,5\%)/ tikus no } 5 \text { (1 } \\
\text { ekor) }\end{array}$ & Pada bagian leher & Diameter $2,8 \mathrm{~cm}$ \\
\hline 2 & $\begin{array}{l}\text { Kelompok II } \\
\text { (Tamoxifen } 0,36 \mathrm{mg} / 200 \mathrm{~g} \mathrm{BB}) / \text { tikus no } 5 \text { (1 } \\
\text { ekor) }\end{array}$ & $\begin{array}{l}\text { Putting bagian kiri no } \\
1 \text { dan } 2\end{array}$ & $\begin{array}{l}\text { Diameter no } 1: 0,3 \\
\mathrm{~cm} ; \text { no } 2: 0,2 \mathrm{~cm}\end{array}$ \\
\hline 3 & $\begin{array}{l}\text { Kelompok V } \\
\text { (Ekstrak } 800 \mathrm{mg} / \mathrm{kg} \mathrm{BB}) / \\
\text { tikus no } 5 \text { (1 ekor) }\end{array}$ & $\begin{array}{l}\text { Pada pinggul bagian } \\
\text { kanan }\end{array}$ & Diameter $2,5 \mathrm{~cm}$ \\
\hline
\end{tabular}

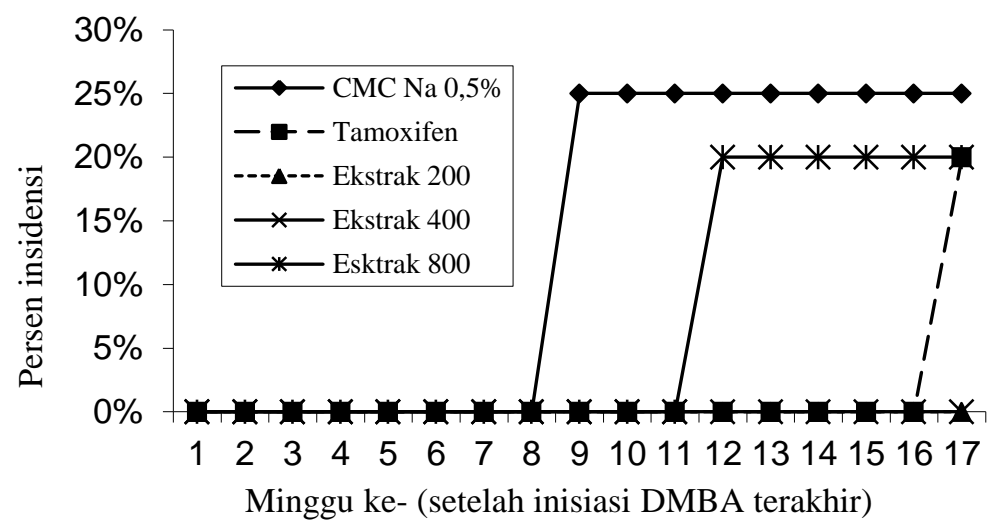

Gambar 1. Profil insidensi tikus yang terkena tumor pada masing-masing perlakuan selama inisiasi dan post inisiasi DMBA. Setiap titik merupakan hasil rata-rata dari $n=5$ selain kelompok CMC Na $(n=4)$. 


\section{Efek Kemopreventif Ekstrak Metanol Kulit Kayu Nangka (Artocarpus heterophylla}

Lmk.) pada Karsinogenesis Kanker Payudara

Persen insidensi pada kelompok kontrol negatif (DMBA+CMC-Na 0,5\%) dengan hasil $25 \%$ (1/4) dalam waktu 9 minggu setelah inisiasi DMBA terakhir, artinya hanya 1 ekor tikus yang terkena tumor mamae $(\mathrm{n}=4)$ dalam waktu 9 minggu setelah inisiasi. Insidensi tumor pada kelompok perlakuan ekstrak 800 $\mathrm{mg} / \mathrm{kg}$ BB adalah $20 \%(1 / 5)$ dalam waktu 12 minggu, artinya hanya 1 ekor tikus yang terkena tumor mamae dari 5 hewan uji. Pada perlakuan ekstrak $200 \mathrm{mg} / \mathrm{kg}$ BB dan $400 \mathrm{mg} / \mathrm{kg}$ BB dengan $0 \%$ insidensi tumor sampai 17 minggu setelah inisiasi menunjukkan tidak terdapat satupun ekor tikus yang terkena tumor mamae $(n=5)$. Adapun untuk perlakuan kontrol positif (Tamoxifen 0,36 mg/200 g BB) adalah $20 \%(1 / 5)$ dalam waktu 17 minggu.
Hasil persen insidensi pada kelompok kontrol negatif (DMBA+CMC $\mathrm{Na} 0,5 \%)$ yang hanya mencapai $25 \%$ menjadi kendala untuk menginterpretasikan persen penghambatan insidensi tumor untuk perlakuan ekstrak (Tabel 2). Walaupun persen penghambatan pada kelompok ekstrak $200 \mathrm{mg} / \mathrm{kg}$ BB dan $400 \mathrm{mg} / \mathrm{kg}$ BB mencapai 100\% (artinya 100\% dapat menghambat tumbuhnya tumor) tetapi belum dapat dikatakan bahwa penghambatan disebabkan oleh pemberian ekstrak, karena menunjukkan adanya faktor lain yang mampu mendorong kegagalan pertumbuhan tumor mamae sehingga pada kelompok kontrol negatif insidensi tumor hanya $25 \%$.

Tabel 2. Jumlah Insidensi Tumor Mammae Tikus Pada Berbagai Perlakuan Tahap Selama dan Post Inisiasi

\begin{tabular}{|c|c|c|c|c|c|}
\hline $\begin{array}{l}\text { Kelompok } \\
\text { perlakuan }\end{array}$ & $\begin{array}{c}\text { Jumlah } \\
\text { tikus yang } \\
\text { diuji }\end{array}$ & $\begin{array}{l}\text { Jumlah tikus } \\
\text { yang terkena } \\
\text { tumor }\end{array}$ & $\begin{array}{c}\text { Insid } \\
\text { ensi } \\
(\%)\end{array}$ & $\begin{array}{l}\text { Waktu latensi } \\
\text { (minggu setelah } \\
\text { inisiasi terakhir) }\end{array}$ & $\begin{array}{c}\text { Pengurangan } \\
\text { (penghambatan } \\
\text { ) }(\%)\end{array}$ \\
\hline $\begin{array}{l}\text { Kontrol Negatif } \\
(\mathrm{CMC} \mathrm{Na} 0,5 \%)\end{array}$ & 4 & 1 & 25 & 9 & - \\
\hline $\begin{array}{l}\text { Kontrol positif } \\
\text { (Tamoxifen 0,36 } \\
\text { mg/200 g BB) }\end{array}$ & 5 & 1 & 20 & 17 & 0 \\
\hline $\begin{array}{l}\text { Ekstrak } 200 \mathrm{mg} / \mathrm{kg} \\
\text { BB }\end{array}$ & 5 & 0 & 0 & - & 100 \\
\hline $\begin{array}{l}\text { Ekstrak } 400 \mathrm{mg} / \mathrm{kg} \\
\text { BB }\end{array}$ & 5 & 0 & 0 & - & 100 \\
\hline $\begin{array}{l}\text { Ekstrak } 800 \mathrm{mg} / \mathrm{kg} \\
\text { BB }\end{array}$ & 5 & 1 & 20 & 12 & 0 \\
\hline
\end{tabular}

Keterangan: Pada kontrol negatif jumlah tikus uji lebih sedikit dikarenakan sebelum inisiasi DMBA terakhir sudah mati (mati pada minggu ke 5 tahap

\section{Pengaruh Pemberian Ekstrak Terhadap Perkembangan Berat Badan}

Perkembangan berat badan tikus pada masing-masing kelompok menunjukkan terjadinya rata-rata kenaikan berat badan tikus semua kelompok seiring bertambahnya usia (Tabel 3 dan Gambar 2). Continuing Profesional Development Dokter Indonesia (2008) menyatakan bahwa pada penderita kanker akan mengalami kehilangan berat badan, dikarenakan sel- sel kanker yang berbahaya dapat mengambil nutrisi dari sel yang sehat. $\mathrm{Hal}$ tersebut menunjukkan adanya hubungan berbanding terbalik antara perkembangan berat badan dengan tumbuhnya tumor. Oleh karena itu, menunjukkan kelompok perlakuan ekstrak dosis $400 \mathrm{mg} / \mathrm{kg}$ BB dengan rata-rata selisih berat badan paling besar diindikasikan memiliki resiko tumbuhnya kanker yang paling kecil tetapi tidak signifikan $(\mathrm{p}>0,05)$. 
Susilowati

Tabel 3. Rata-rata Selisih Berat Badan Tikus yang Ditimbang Setiap Minggu Selama Percobaan (23 Minggu) dari $n=5$

\begin{tabular}{lc}
\hline \multicolumn{1}{c}{ Kelompok } & $\begin{array}{c}\text { Rata-rata selisih berat badan tikus } \pm \text { SD } \\
{\left[\frac{B B(\text { mingguke23-mingguke1) }}{23}\right]}\end{array}$ \\
\hline Kontrol negatif & $3.40 \mathrm{~g} \pm 3.48$ \\
Kontrol positif & $4.18 \mathrm{~g} \pm 1.00$ \\
Dosis $200 \mathrm{mg} / \mathrm{kg} \mathrm{BB}$ & $4.36 \mathrm{~g} \pm 0.70$ \\
Dosis $400 \mathrm{mg} / \mathrm{kg} \mathrm{BB}$ & $5.63 \mathrm{~g} \pm 0.78$ \\
Dosis $800 \mathrm{mg} / \mathrm{kg} \mathrm{BB}$ & $4.91 \mathrm{~g} \pm 0.68$ \\
\hline
\end{tabular}

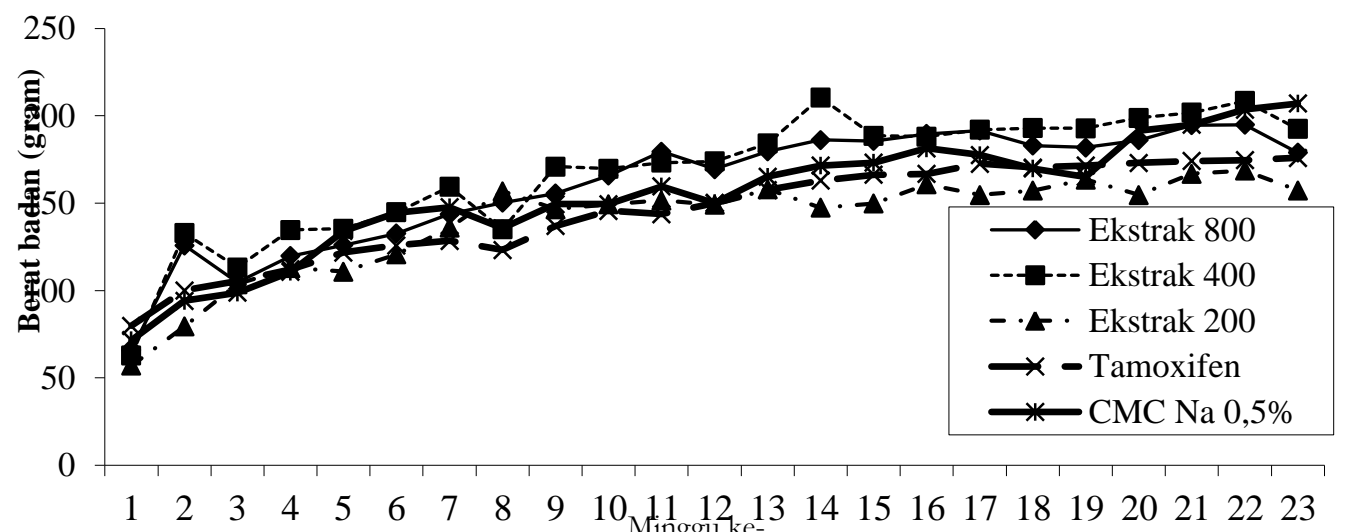

Gambar 2. Perkembangan berat badan tikus perlakuan DMBA pada masing-masing kelompok yang ditimbang setiap minggu selama inisiasi dan post inisiasi terakhir.

\section{Pengaruh Pemberian Ekstrak \\ Terhadap Tumor Multiplicity}

Rata-rata jumlah nodul tumor tiap tikus (tumor multiplicity) kelompok DMBA lebih tinggi dari pada rata-rata jumlah nodul tumor ekstrak $800 \mathrm{mg} / \mathrm{kg}$ BB dan lebih rendah dari pada kontrol positif (Tamoxifen $0,36 \mathrm{mg} / \mathrm{kg} \quad \mathrm{BB}$ ) (Gambar 3). Pada kelompok ekstrak 200 dan $400 \mathrm{mg} / \mathrm{kg}$ BB tidak menunjukkan adanya pertumbuhan tumor selama pengamatan, namun tidak dapat menunjukkan efek penghambatanya dikarenakan kemungkinan terdapatnya faktor lain yang mampu menghambat pertumbuhan tumor mamae selain pengaruh dari ekstrak ataupun tamoxifen.

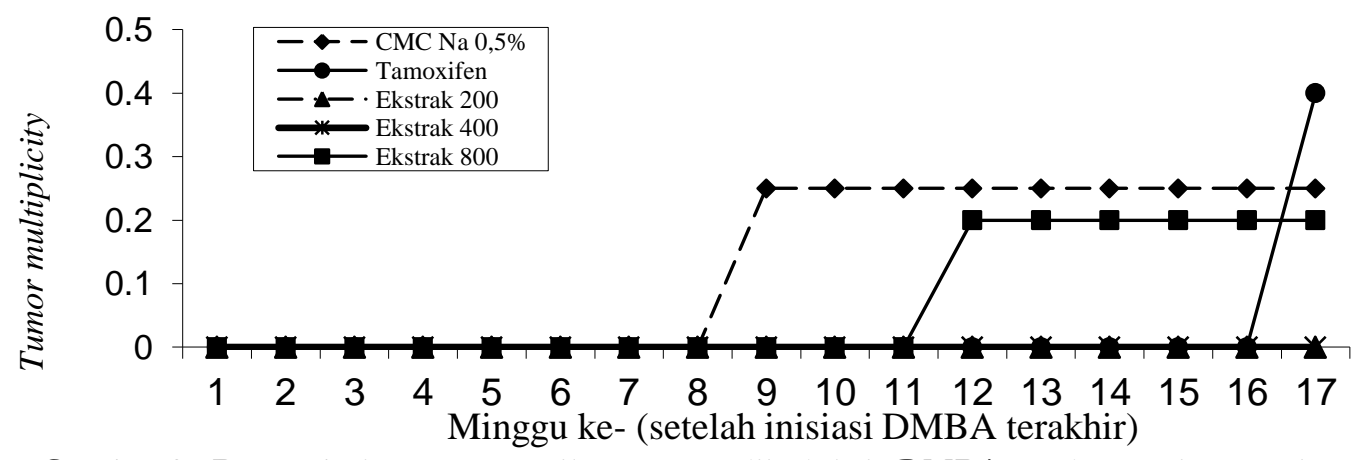

Gambar 3. Pertumbuhan tumor tikus yang diinduksi DMBA pada masing-masing kelompok perlakuan. 


\section{Efek Kemopreventif Ekstrak Metanol Kulit Kayu Nangka (Artocarpus heterophylla}

Lmk.) pada Karsinogenesis Kanker Payudara

\section{E. Perbedaan Histopatologi Antar Perlakuan}

Pada hasil pengamatan secara mikroskopis dengan metode pengecatan Haematoxillin dan Eosin yang terlihat pada Gambar 4 menunjukkan nodul tumor yang diperiksa benar terdapat indikasi kanker yaitu adenokarsinoma. Pada glandula mammae tikus yang terkena tumor, secara histologis menunjukkan terjadinya proliferasi dari epitel acini ke arah lumen acini dengan adanya penebalan ukuran epitel yang bervariasi dan terjadi peradangan berat. Sedangkan pada glandula mammae tikus normal hanya ditemukan satu lapis sel epitel dan diantara acinus hanya ditemukan lapisan tipis. Gambaran histologis pada tikus kelompok perlakuan dosis $400 \mathrm{mg} / \mathrm{kg}$ BB

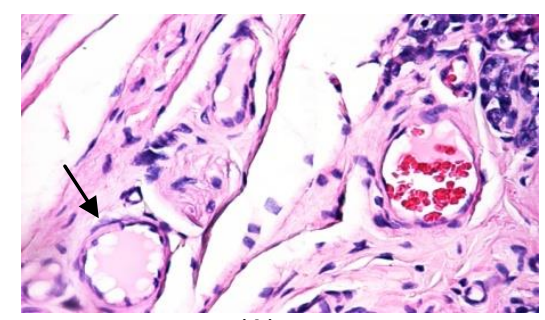

(A)

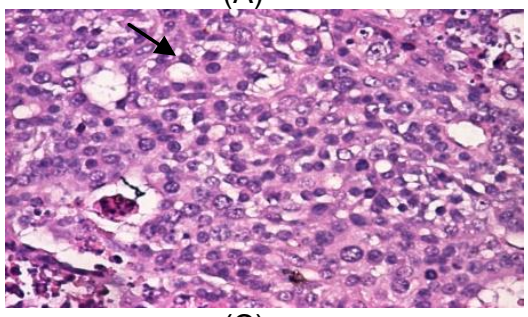

(C) hanya menunjukkan proses menuju terbentuknya tumor, dimana adanya bipertrophy (terjadi pembesaran sel) pada lapis sel epitel sehingga belum terbentuk tumor.

Hasil pengecatan AgNOR yang terlihat pada Gambar 5 mencerminkan indeks prognosis kanker payudara yang terjadi. Dari pengamatan menunjukkan bahwa AgNOR pada sel payudara yang terindikasi tumor cenderung irregular dan lebih tersebar pada sitoplasma. Derajat diferensiasi tersebut secara umum berhubungan dengan tingkat keganasan dan proliferasi sel, sehingga tumor yang derajat diferensiasinya buruk akan mempunyai tingkat proliferasi yang tinggi dimana tercermin dari nilai AgNOR yang lebih tinggi.

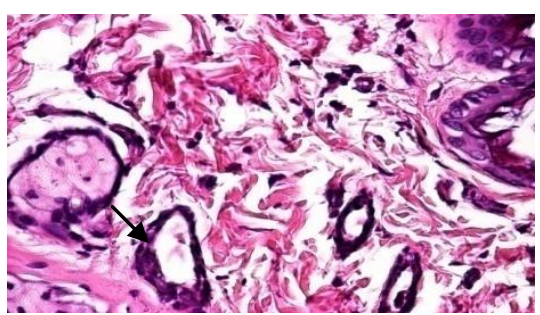

(B)

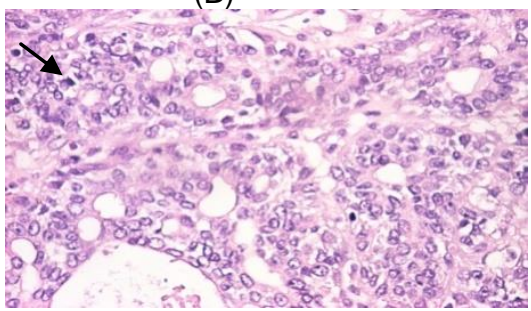

(D)

Gambar 4. Perbedaan gambaran mikroskopis sel mamae pada beberapa perlakuan yang diambil pada minggu ke 17 setelah pemberian DMBA terakhir dengan pengecatan H\&E. (A) Jaringan kelenjar mamae tikus normal (tanpa perlakuan) dan (B) Tikus yang tidak terkena tumor dari kelompok perlakuan ekstrak $400 \mathrm{mg} / \mathrm{kg}$ BB. (C) Jaringan kelenjar mamae tikus terkena tumor pada kontrol negatif (DMBA+CMC Na) dan (D) tikus terkena tumor dari kelompok perlakuan ekstrak $800 \mathrm{mg} / \mathrm{kg}$ BB. (A) pembesaran $400 \mathrm{x}$ dan (B, C, D) pembesaran 200x ( $\triangle$ lumen acini).

Perhitungan kuantitatif NOR per inti memberikan gambaran yang digunakan sebagai petunjuk dalam menentukan prognosis kanker. Analisis statistik terhadap jumlah NOR payudara dan beberapa organ dari interpretasi pengecatan AgNOR, memperlihatkan tidak adanya perbedaan yang signifikan terhadap jumlah NOR payudara masing- masing kelompok. Kelompok kontrol negatif (DMBA) dengan adanya indikasi tumor memiliki rata-rata jumlah NOR yang lebih besar dibandingkan kelompok perlakuan lain (Tabel 4). Hal ini menunjukkan adanya gambaran mitosis yang disebabkan adanya insidensi tumor mamae pada salah satu hewan uji tetapi tidak signifikan. 


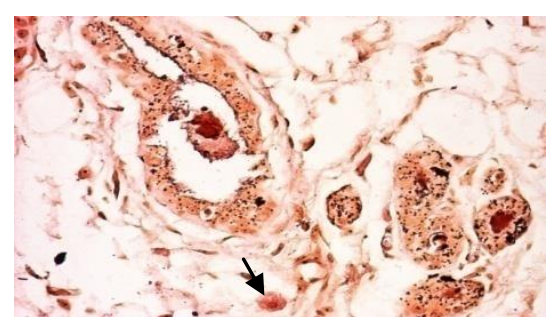

(A)

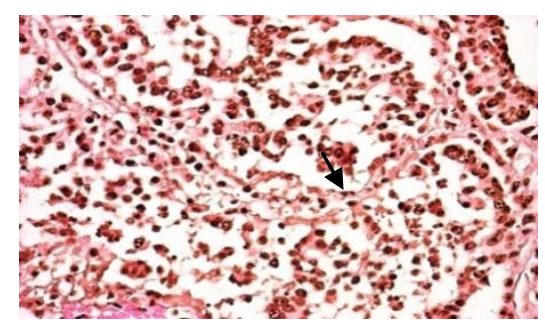

(C)

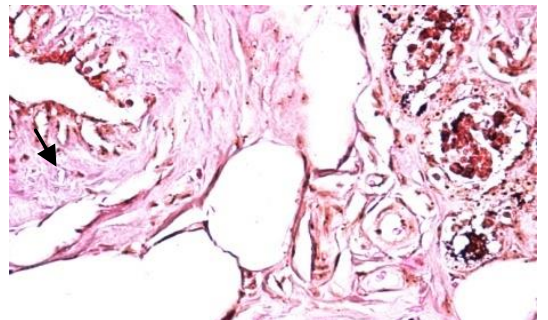

(B)

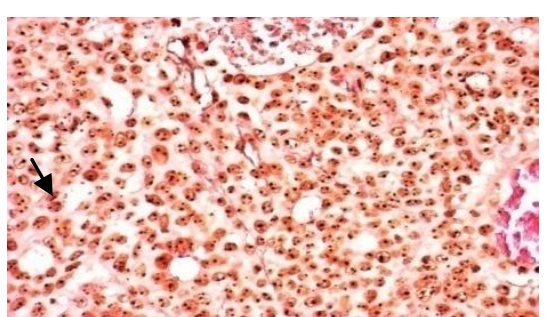

(D)

Gambar 5. Perbedaan gambaran mikroskopis sel mamae pada beberapa perlakuan yang diambil pada minggu ke 17 setelah pemberian DMBA terakhir dengan pengecatan AgNOR. (A) Jaringan kelenjar mamae tikus normal (tanpa perlakuan) dan (B) Tikus yang tidak terkena tumor dari kelompok perlakuan ekstrak $400 \mathrm{mg} / \mathrm{kg}$ BB. (C) Jaringan kelenjar mamae tikus terkena tumor pada kontrol negatif (DMBA+CMC Na) dan (D) tikus terkena tumor dari kelompok perlakuan ekstrak $800 \mathrm{mg} / \mathrm{kg}$ BB. (A) pembesaran 400x dan (B, C, D) pembesaran 200x ( $\downarrow$ : NOR dalam sel).

Tabel 4. Data Jumlah NOR Pada Jaringan Payudara, Organ Ginjal, Paru-paru, Hati dan Jantung dari Pengecatan AgNOR

\begin{tabular}{l|c|c|c|c|c}
\hline \multirow{2}{*}{ Kelompok } & \multicolumn{5}{|c}{ Rata-rata jumlah NOR tiap sel masing-masing jaringan organ \pm SD } \\
\cline { 2 - 6 } & Payudara & Ginjal & Paru-paru & Hati & Jantung \\
\hline Kontrol negatif $(\mathrm{n}=3)$ & $1.5 \pm 0.18$ & $1.22 \pm 0.03$ & $1.17 \pm 0.04$ & $1.45 \pm 0.13$ & $1.27 \pm 0.11$ \\
Kontrol positif $(\mathrm{n}=3)$ & $1.31 \pm 0.06$ & $1.21 \pm 0.06$ & $1.23 \pm 0.06$ & $1.47 \pm 0.09$ & $1.15 \pm 0.11$ \\
Ekstrak 200 $(\mathrm{n}=3)$ & $1.32 \pm 0.14$ & $1.3 \pm 0.04$ & $1.34 \pm 0.05$ & $1.68 \pm 0.16$ & $1.17 \pm 0.18$ \\
Ekstrak 400 $(\mathrm{n}=3)$ & $1.25 \pm 0.10$ & $1.36 \pm 0.21$ & $1.15 \pm 0.07$ & $1.51 \pm 0.19$ & $1.26 \pm 0.15$ \\
Ekstrak 800 $(\mathrm{n}=3)$ & $1.43 \pm 0.18$ & $1.23 \pm 0.17$ & $1.27 \pm 0.01$ & $1.36 \pm 0.18$ & $1.2 \pm 0.08$ \\
Normal $(\mathrm{n}=1)$ & 1.21 & 1.33 & 1.65 & 1.26 & 1.2 \\
\hline
\end{tabular}

Pengamatan histologis terhadap beberapa organ yang meliputi hati, jantung, paru dan ginjal bertujuan untuk mengetahui tingkat metastase tumor. Dari analisa hasil pengecatan HE serta rata-rata jumlah NOR, tidak menunjukkan adanya perbedaan signifikan dengan sel jaringan organ tikus normal. Hal tersebut menunjukkan bahwa belum terjadi metastase kanker dari payudara ke organ lain.

Pada penelitian ini ekstrak metanol kulit kayu nangka (Artocarpus heterophylla Lmk.) diharapkan mampu menghambat timbulnya kanker akibat induksi dari DMBA. Akan tetapi, hasil penelitian menunjukkan ketidakberhasilan insidensi tumor mamae pada kelompok kontrol negatif yang dikarenakan adanya faktor lain yang mendorong terjadinya kegagalan pertumbuhan tumor mamae pada kelompok kontrol negatif selain pengaruh dari ekstrak dan tamoxifen, sehingga pertumbuhan tumor tidak terjadi pada keseluruhan hewan uji.

Faktor ketidakberhasilan insidensi tersebut dimungkinkan karena menurunnya kualitas DMBA akibat penyimpanan yang terlalu lama sehingga menurunkan stabilitas sediaan dan masih diragukannya kemurnian tikus galur Sprague-Dawley yang digunakan dengan 
kondisi kandang yang belum terstandar sehingga berakibat penurunan efek karsinogenik DMBA. Selain itu dimungkinkan karena variasi individual dari masing-masing hewan uji untuk mengalami karsinogenesis, dimana proses molekulernya dalam tubuh yang komplek dan tiap individu memiliki tanggapan yang berbeda.

Menurut Kubatka et al. (2002) faktor musim juga berpengaruh pada kejadian karsinogenesis, dengan hasil yang menunjukkan bahwa kejadian karsinogenesis mammae pada tikus betina galur Sprague-Dawley memiliki insidensi tumor yang paling rendah pada musim dingin dibandingkan musim biasa/panas. $\mathrm{Hal}$ ini menunjukkan faktor yang menyebabkan rendahnya insidensi tumor yang dihasilkan pada percobaan juga dimungkinkan karena percobaan dilakukan selama musim dingin. Oleh karena itu, hasil penelitian belum dapat digunakan untuk mengetahui efek kemopreventif ekstak metanol nangka terhadap karsinogenesis kanker payudara pada tikus putih betina galur SD yang diinduksi DMBA.

\section{KESIMPULAN}

Berdasarkan hasil penelitian, belum dapat diketahui efek kemopreventif ekstrak metanol kulit kayu nangka (Artocarpus heterophylla Lmk.) untuk menurunkan kejadian tumor payudara selama inisisai dan post inisiasi kanker pada tikus putih betina galur Sprague Dawley yang diinduksi DMBA.

\section{SARAN}

1. Perlu dilakukan penelitian lebih lanjut terhadap model induksi karsinogenesis kanker payudara pada hewan uji tikus dengan karsinogen DMBA (7,12-dimetilben ₹(a)antrasen).

2. Perlu adanya penelitian ulang untuk mengetahui efek kemopreventif ekstrak metanol kulit kayu nangka terhadap karsinogenesis kanker payudara.

\section{DAFTAR PUSTAKA}

Arung, E.T., E. Sukaton, K., Shimizu, S., Muladi, R., and Kondo., 2008. Artocarpin, A Promosing Compound as Whitening Agent and Anti-skin Cancer, Journal Tropical Wood Science and Technology, Vol. 6, No. 1, 1-36

Barros, C.A.S.D., Muranaka, E.N.K., Mori, L.J., Pelizon, C.H.T., Iriya, K., Giocondo, G., and Pinotti, J.A., 2004, Induction of Experimental Mammary Carcinogenesis in Rats with 7,12Dimethylbenz (a)antracene, Rev. Hosp. Clin. Fac. Med. S. Paulo, 59(5):257-261

Continuing Profesional Development Dokter Indonesia, 2008, Kenali Tanda dan Gejala Kanker Pankreas. Majalah Dokter Indonesia, (online) (http://cpddokter.com, diakses 21 Desember 2009)

Ersam, T., 2001, Senyawa Kimia Makromolekul beberapa Tumbuhan Artocarpus Hutan Tropika Sumatera Barat, Disertasi, ITB, Bandung

Gerhauser, C., 2008, Cancer Chemoprevention, (online), (http://www.dkfz.de/en/tox/canc er-chemoprevention.html, diakses 21 Februari 2009)

Gunawan, S. G., 2007, Farmakologi dan Terapi Edisi 5, Departemen Farmakologi dan Teraupetik Fakultas Kedokteran UI, Jakarta

Kakizoe, T., 2003, Chemoprevention of Cancer Focusing on Cinical Trial, Nationa Cancer Center, Jpn.J.Clin.Oncol., 33(9): 421-442

King, R.J.B., 2000, Cancer Biology, 2nd ed, Pearson Education Limited, London

Kubatka, P., Ahlersova E., Ahlers I., Bojkova B., Kalicka K., Adamekova E., Markova, M., Chamilova, M., and Cermakova, M., 2002, Variability of Mammary Carcinogenesis Induction in Female Sprague-Dawley and Wistar: Hans 


\section{Susilowati}

Rats: the Effect of Seasons, Safarik University, Slovak Republic, p. 633-640

Meiyanto, E., Tasminatun, S., Susilowati, S., Murwanti, R., dan Sugiyanto, 2007, Penghambatan karsinogenesis kanker payudara tikus terinduksi DMBA pada fase post inisiasi oleh ekstrak etanolik daun Gynura procumbens (Lour), Merr, Majalah Farmasi Indonesia, 18(4), $169-175$

Ren, W., Qiao, Z., Wang, H., Zhu, L., and Zhang, L., 2003, Flavonoids: Promising Anticancer Agents, Medicinal Research Review, 23(24): 519-534.

Russo, J., and Russo I.H., Toward a physiological Approach to Breast Cancer Prevention, Cancer Epidemiol Biomark Prev 1994;3;353-64

Sampurno, 2003, Beberapa Tanaman yang Berkhasiat Sebagai Anti Kanker, Badan Pengawasan Obat dan Makanan Republik Indonesia, Jakarta (http://www.pom.go.id, diakses 21 Februari 2009)
Suhartati, 2001, Senyawa Fenol Beberapa Spesies Tumbuhan Jenis Cempedak Indonesia, Thesis, Fakultas Kimia ITB, Bandung

Susilowati, S., 2004, Efek Kemopreventif Ekstrak Etanol daun Gynura procumbens (Lour) Merr Terhadap Kanker Payudara Tikus yang Diinduksi DMBA, Tesis, UGM, Yogyakarta

Syah, Y.M., 2005, Fitokimia, Kemotaksonomi dan sifat Biologis metabolit sekunder dari tanaman Sukun (Keluwih), Bulletin of The Indonesian Society of Natural Product Chemistry, 5(2), July-Desember, 3350

Tjindarbumi, D., dan Mangunkusumo, R., 2002, Cancer indonesia Indonesia, Present and Future, Jpn Jclin Oncol: 32 (Suplement 1): 517:521

Wiludjeng, L.K., dan Turniani, L., 2005, Epidemologi Penyakit Kanker Payudara, Pusat Penelitian Pengembangan Pelayanan Teknologi Kesehatan, Surabaya 